\title{
PENGARUH ASUPAN MAKANAN TERHADAP KEJADIAN MALNUTRISI DI RUMAH SAKIT
}

\author{
Defriani Dwiyanti ${ }^{1}$, Hamam Hadi $^{2}$, Susetyowati ${ }^{3}$
}

\begin{abstract}
Background: Sufficient food and other nutrient intake are necessary for recovery of hospitalized patients. Insufficient food intake may decrease nutrient metabolism, which in turn may cause malnutrition. Malnutrition in all hospital is categorized as high (about 40-45\%). However, the influence of food intake on hospital malnutrition in Indonesia is still unknown.

Objective: To assess the influence of nutrient intake on the occurence of hospital malnutrition.

Methods: This was an observational with prospective cohort study. This study was conducted in Dr. M. Jamil Padang Hospital, Dr. Sardjito Yogyakarta Hospital, and Sanglah Denpasar Hospital. Subjects were 228 adult patients from internal and neurology units in $1^{\text {st }}, 2^{\text {nd }}$, and $3^{r d}$ class who were hospitalized for six days or more, receiving oral diet, compos mentis, cooperative, non edema, and non ascites. Data of body weight and body height were measured at admission and discharge. Food intake data collected in this study included hospital and non-hospital food. Data analyzed by FP2 programme and STATA software.

Results: Among 228 subjects of study, 51,8\% had insufficient intake in the first three days of hospitalization. On average, their protein and energy intakes were lower than subjects with sufficient intake. There was a significant correlation between the first three days intake and intake during hospitalization $(p<0,05)$. Subjects with insufficient energy intake were 2,1 times more likely to be malnourished in hospital than subjects with sufficient energy intake. Meanwhile, subjects with insufficient protein intake were 1,56 times more likely to be malnourished than subjects with sufficient protein intake. There was a significant association between energy intake and hospital malnutrition $(p<0,05)$.

Conclusions: Patients with insufficient nutrient intakes are more likely to be malnourished than those with sufficient nutrient intakes.
\end{abstract}

Key words: food intake, hospital malnutrition, hospitalized patients.

\section{PENDAHULUAN}

Malnutrisi merupakan salah satu permasalahan yang dihadapi rumah sakit dalam upaya penyembuhan pasien. Angka malnutrisi ini cukup tinggi dan merata hampir di semua rumah sakit untuk

\footnotetext{
Jurusan Gizi Poltekes Padang

Magister Gizi dan Kesehatan, IKM, Pascasarjana UGM, Yogyakarta

3 Instalasi Gizi RS Dr. Sardjito, Yogyakarta
}

semua jenis penyakit maupun sosial ekonomi penderita (1). Malnutrisi dapat timbul sejak sebelum dirawat di rumah sakit yang disebabkan karena penyakitnya atau masukan zat gizi yang tidak cukup, namun tidak jarang pula malnutrisi ini timbul selama dirawat inap (2).

Penelitian yang dilakukan oleh McWhirter dan Pennington (3) menunjukkan bahwa $40 \%$ dari pasien mengalami undernourish (kurang makan) pada saat masuk rumah sakit dan dua pertiga dari pasien itu mengalami penurunan berat badan selama dirawat di rumah sakit. Penelitian ini tidak jauh berbeda dengan yang dikemukakan oleh Daldiyono dan Thaha (4) yang mengutip dari beberapa penelitian, memprediksi 40-55\% pasien yang masuk rumah sakit mengalami malnutrisi atau memiliki risiko malnutrisi, $12 \%$ di antaranya merupakan malnutrisi berat. Ratarata $75 \%$ status gizi penderita yang dirawat di rumah sakit akan menurun dibandingkan dengan status gizi pada waktu masuk rumah sakit (4). Faktor penyebab berkurangnya cadangan zat gizi di dalam tubuh biasanya karena penyakit dan defisiensi zat gizi serta tidak cukupnya asupan makanan, hal ini akan berdampak pada komplikasi (5).

Penelitian ini dilakukan untuk mengetahui hubungan rata-rata asupan energi tiga hari pertama (asupan awal) dengan rata-rata asupan energi dan protein pasien selama dirawat di rumah sakit serta pengaruh asupan makanan (energi dan protein) yang tidak cukup terhadap terjadinya malnutrisi di rumah sakit.

\section{BAHAN DAN METODE}

Penelitian ini adalah penelitian observasional dengan rancangan studi kohor prospektif, yang dilakukan pada dua bangsal yaitu bangsal penyakit dalam dan saraf di tiga rumah sakit yaitu RS Dr. M. Jamil Padang, RS Dr. Sardjito Yogyakarta dan RS Sanglah Denpasar sejak bulan Oktober 2002 sampai Februari 2003. Penelitian ini merupakan bagian dari suatu penelitian yang dirancang untuk melihat 
pengaruh makanan, status gizi dan faktor lain terhadap hospital outcomes. Penelitian ini lebih dikenal dengan sebutan Penelitian SARMILA, merupakan singkatan dari Sardjito, Jamil dan Sanglah.

Subjek penelitian ini adalah pasien dewasa dengan usia di atas 18 tahun, minimal dirawat inap di rumah sakit selama 6 hari, kesadaran compos mentis dan kooperatif, tidak oedema dan asites. Pada awal penelitian, jumlah pasien yang memenuhi kriteria inklusi berjumlah 318 orang, dan setelah dilakukan pengamatan sampai pasien meninggalkan rumah sakit jumlah ini menjadi 228 orang, hal ini disebabkan karena 87 orang lama rawatnya kurang dari 6 hari dan 3 orang pindah ruang. Subjek yang memenuhi kriteria inklusi dibagi menjadi dua kelompok yaitu kelompok terpapar berjumlah 118 orang dan kelompok tidak terpapar berjumlah 110 orang. Pengelompokkan ini berdasarkan rata-rata asupan energi tiga hari pertama. Subjek termasuk ke dalam kelompok terpapar (asupan awal tidak cukup) bila asupan rata-rata energi tiga hari pertama $<75 \%$ kebutuhan dan kelompok tidak terpapar (asupan awal cukup) bila 75\% kebutuhan.

Data yang dikumpulkan meliputi asupan makanan diperoleh dengan menggunakan metode Comstock dan Food Recall 24 jam yang dilihat selama dirawat di rumah sakit. Asupan makanan ini dikonversikan dalam bentuk energi dan protein dengan menggunakan software Food Processor 2 yang kemudian dibandingkan dengan kebutuhan pasien yang ditentukan dengan menggunakan rumus Harris Benedict, kemudian dikelompokkan menjadi dua kelompok yaitu asupan makanan cukup bila $.75 \%$ dari kebutuhan dan asupan makanan tidak cukup bila $<75 \%$ kebutuhan.

Data yang berkaitan dengan kejadian malnutrisi di rumah sakit dilihat dari perubahan berat badan. Berat badan ini diukur pada awal masuk dan menjelang pasien pulang dengan menggunakan timbangan merk Camry dengan ketelitian 0,1 kg. Data mengenai jenis kelamin, umur, kelas rawat, lama rawat, penyakit, terapi medis, dan perkembangan penyakit dikumpulkan dengan menggunakan kuesioner terstruktur. Keseluruhan data dikumpulkan oleh tenaga gizi terlatih lulusan D-III Poltekes Jurusan Gizi.

Data yang telah dicek kelengkapannya dimasukkan ke dalam komputer dan dianalisis dengan menggunakan software STATA versi 6,0. Variabel outcome penelitian ini adalah malnutrisi yang berskala ordinal yaitu malnutrisi bila terjadi penurunan berat badan selama di rumah sakit dan tidak malnutrisi bila tidak terjadi penurunan atau bila berat badannya meningkat. Variabel bebas penelitian ini adalah asupan makanan selama dirawat dalam bentuk skala ordinal yaitu asupan cukup bila lebih atau sama dengan $75 \%$ kebutuhan dan tidak cukup bila kurang dari $75 \%$ kebutuhan. Variabel yang dikendalikan yaitu penyakit dan terapi medis. Uji statistik yang digunakan adalah uji regresi, Chi Square dan regresi ganda logistik untuk mengendalikan variabel pengganggu.

\section{HASIL DAN BAHASAN}

\section{Karakteristik Subjek Penelitian}

Berdasarkan asal rumah sakit, distribusi terbesar subjek penelitian ini adalah RS Dr. M. Jamil (37,3\%), RS Sanglah $(36,4 \%)$, dan RS Dr. Sardjito $(26,3 \%)$. Distribusi subjek berdasarkan asal rumah sakit ada perbedaan bermakna $(p<0,05)$ antara kedua kelompok. Sebagian besar $(54,6 \%)$ berjenis kelamin laki-laki dan $47,4 \%$ berjenis kelamin perempuan. Distribusi subjek berdasarkan jenis kelamin ada perbedaan bermakna $(p<0,05)$ antara kedua kelompok (Tabel 1).

Sampel terbesar pada kelompok dengan asupan awal tidak cukup sebanyak 32 orang $(27,1 \%)$ dan kelompok dengan asupan awal cukup sebanyak 35 orang $(31,8 \%)$ yang tersebar pada kelompok umur lebih dari 57 tahun. Tidak ada perbedaan distribusi subjek penelitian antara kedua kelompok menurut umur $(p>0,05)$ (Tabel 1).

Berdasarkan kelas perawatan, distribusi terbesar subjek terdapat pada kelas III, yaitu 65 orang $(55,0 \%)$ pada kelompok dengan asupan awal tidak cukup dan 56 orang $(50,9 \%)$ pada kelompok asupan awal cukup serta tidak ada perbedaan antara kedua kelompok tersebut $(p>0,05)$ (Tabel 1). Distribusi terbesar pasien dirawat lebih dari 7 hari yaitu sebanyak 82 orang $(69,5 \%)$ pada kelompok asupan awal tidak cukup dan 78 orang $(70,9 \%)$ pada kelompok asupan awal cukup, serta tidak ada perbedaan lama rawat antara kedua kelompok tersebut $(p>0,05)$ (Tabel 1).

Bila dilihat dari penyakit, distribusi terbesar subjek termasuk berpenyakit noninfeksi yaitu sebanyak 81 orang $(68,6 \%)$ pada kelompok asupan awal tidak cukup dan 88 orang $(80 \%)$ pada kelompok asupan awal cukup, serta distribusi subjek berdasarkan penyakit tidak ada perbedaan antara kedua kelompok $(p>0,05)$ (Tabel 1). Berdasarkan terapi medis yang dijalani pasien di rumah sakit, distribusi terbesar subjek yaitu termasuk ke dalam kategori asupan awal cukup dan tidak mendapat terapi medis sebanyak 73 orang $(66,4 \%)$. Distribusi subjek 
Tabel 1. Distribusi Karakteristik Subjek

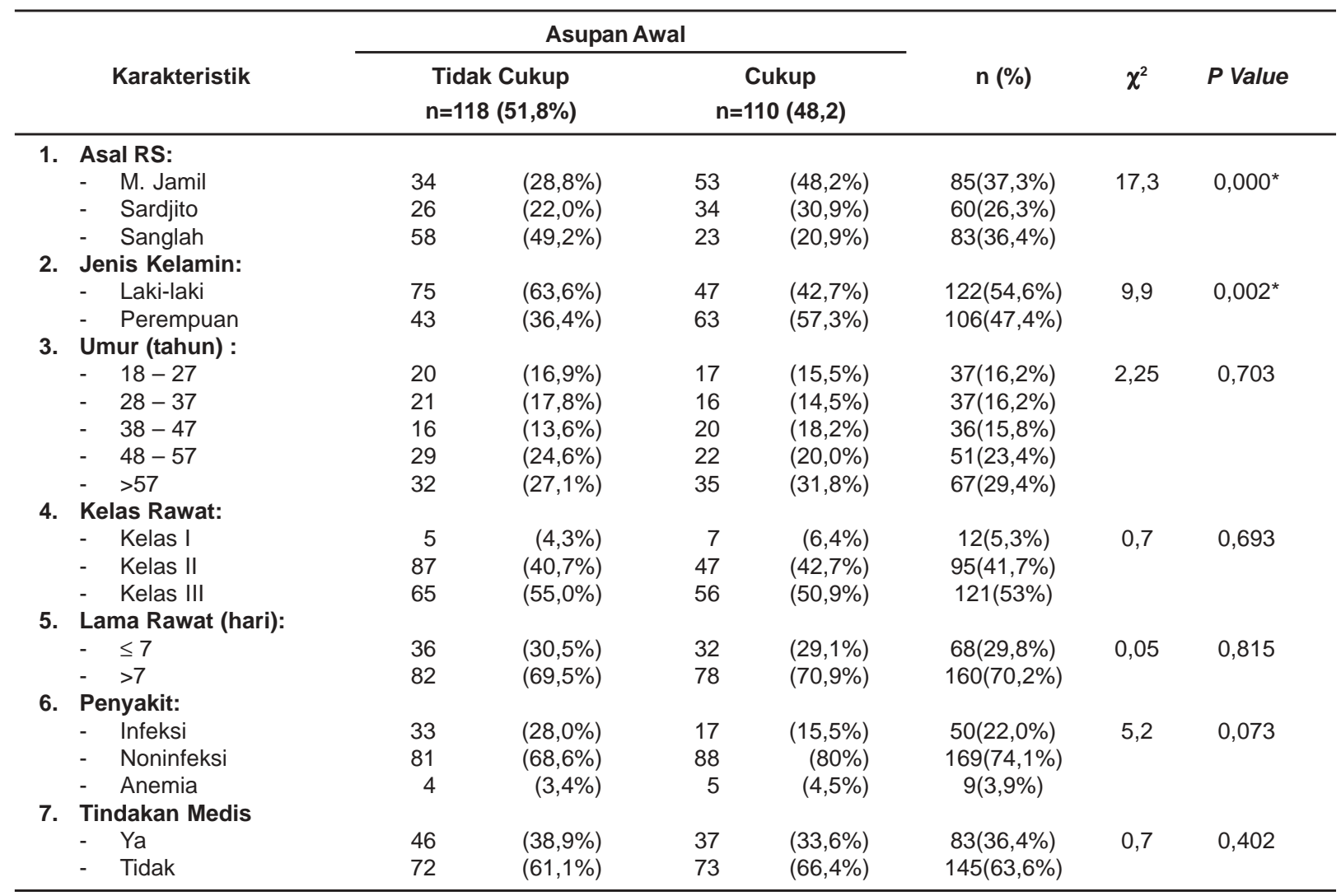

* Bermakna dengan uji Chi Square $(p<0,05)$

Rata-rata asupan energi tiga hari pertama

Tabel 2. Rata-Rata Asupan Makanan Subjek selama Dirawat di Rumah Sakit

\begin{tabular}{ccc}
\hline & Asupan Awal & \\
Variabel & Tidak Cukup & Cukup \\
& Mean \pm SD & Mean \pm SD \\
\hline Energi (Kkal) & $1315,6 \pm 343,4$ & $1820,4 \pm 368,0$ \\
Protein (gram) & $40,4 \pm 11,3$ & $57,9 \pm 11,7$ \\
\hline
\end{tabular}

Rata-rata asupan energi tiga hari pertama berdasarkan terapi medis ini juga tidak ada perbedaan antara kedua kelompok ( $p>0,05)$ (Tabel 1).

Berdasarkan diagnosis penyakit antar rumah sakit, maka terlihat bahwa jenis penyakit yang terbanyak diderita subjek untuk tiga rumah sakit adalah penyakit noninfeksi yaitu $81 \%$ untuk RS Dr. M. Jamil, 80\% untuk RS Dr. Sardjito, dan 63\% untuk RS Sanglah (Gambar 1).

Berdasarkan terapi medis antar rumah sakit maka terlihat bahwa distribusi terbesar subjek yang mendapat terapi medis adalah di RS Sanglah yaitu

Tabel 3. Tingkat Kecukupan Energi dan Protein Subjek Selama di Rumah Sakit

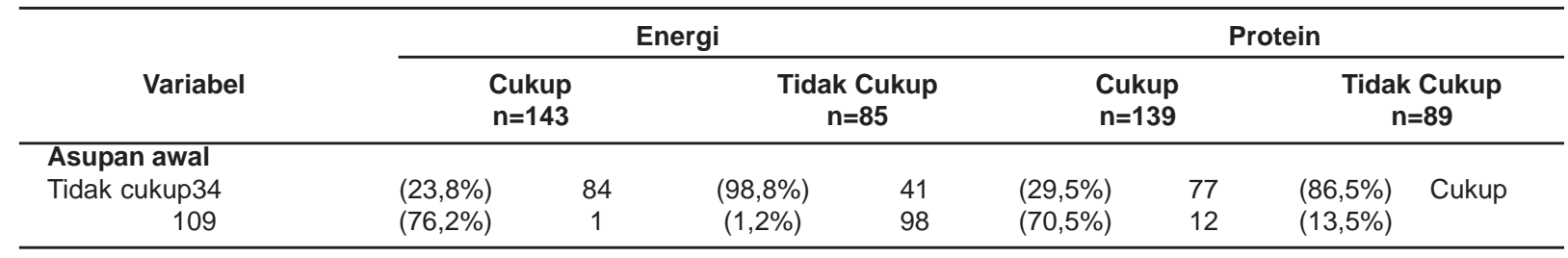

Rata-rata asupan energi tiga hari pertama 


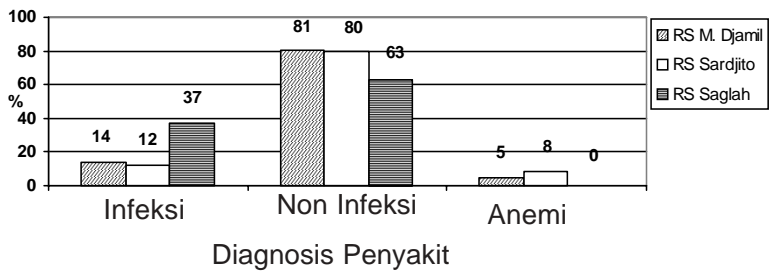

Gambar 1. Diagnosis Penyakit antar Rumah Sakit

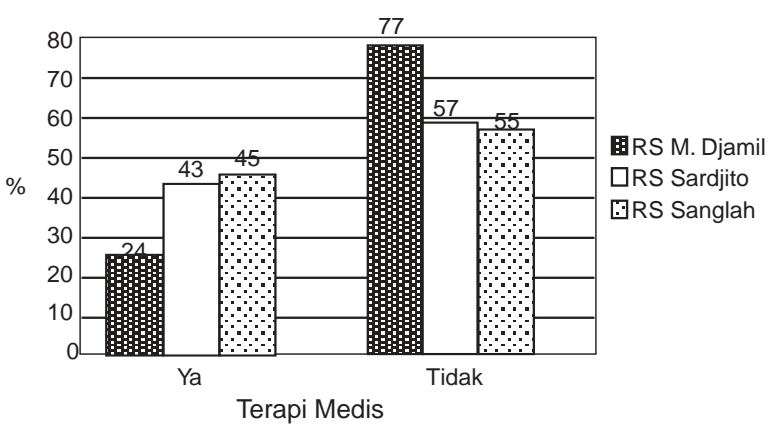

Gambar 2. Terapi Medis antar Rumah Sakit

sebesar 45\%, kemudian diikuti RS Dr. Sadjito 43\% dan RS Dr. M. Jamil 23\% (Gambar 2).

Rata-rata asupan makanan subjek selama di rumah sakit yang asupan awalnya tidak cukup jumlahnya lebih rendah daripada kelompok asupan awal cukup yaitu untuk energi 1315,6 Kkal dengan SD $\pm 343,4$ dan protein 40,4 gram dengan SD $\pm 1,3$ (Tabel 2). Dilihat dari kecukupannya, subjek yang pada awal masuk asupannya tidak cukup dan selama perawatan asupannya terus menerus tidak cukup berjumlah 84 orang $(98,8 \%)$ untuk asupan energi dan 77 orang $(86,5 \%)$ untuk asupan protein. Subjek yang mempunyai asupan cukup pada awal masuk namun asupannya menjadi tidak cukup selama dirawat di rumah sakit berjumlah 1 orang $(1,2 \%)$ untuk energi dan 12 orang (13,5\%) untuk protein (Tabel 3). Subjek yang dikategorikan malnutrisi selama di rumah sakit

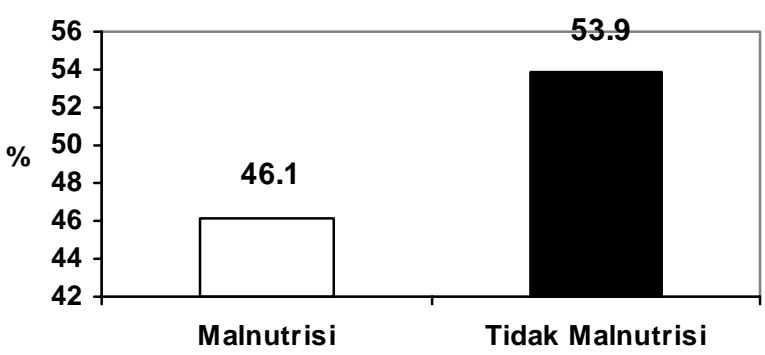

Gambar 3. Persentase Kejadian Malnutrisi sebanyak 105 orang $(46,1 \%)$ dan tidak malnutrisi sebanyak 123 orang (53,9\%) (Gambar 3).

\section{Hubungan Rata-Rata Asupan Energi 3 Hari Pertama dengan Rata-Rata Asupan Makanan selama di RS}

Berdasarkan analisis statistik, diperoleh hasil bahwa ada hubungan yang signifikan antara ratarata asupan energi tiga hari pertama dengan rata-

Tabel 4. Hubungan Rata-rata Asupan Energi Tiga Hari Pertama dengan Rata-rata Asupan Makanan selama di Rumah Sakit

\begin{tabular}{lcccc}
\hline Variabel & $\begin{array}{c}\text { Koefisen } \\
\text { regresi }\end{array}$ & $\begin{array}{c}\text { Standard } \\
\text { Error }\end{array}$ & P-Value & $\mathbf{R}^{2}$ \\
\hline Energi & 0,81 & 0,03 & $0,00^{*}$ & 0,72 \\
Protein & 0,02 & 0,001 & $0,00^{*}$ & 0,52 \\
\hline
\end{tabular}

*Bermakna signifikan dengan uji Regresi $(p<0,05)$

rata asupan selama di rumah sakit, baik untuk energi maupun protein $(p<0,05)$ (Tabel 4$)$.

\section{Pengaruh Asupan Makanan terhadap Kejadian Malnutrisi di Rumah Sakit}

Subjek dengan asupan yang tidak cukup dan mengalami malnutrisi berjumlah 49 orang $(46,7 \%)$ untuk asupan energi tidak cukup dan 47 orang $(44,8 \%)$ untuk asupan protein tidak cukup. Jika dilihat dari Odds Rasio, subjek dengan asupan energi tidak cukup mempunyai risiko 2,1 (Cl 1,23-3,65) kali lebih besar untuk mengalami malnutrisi dibandingkan dengan subjek dengan asupan energi cukup. Sedangkan untuk protein, subjek dengan asupan protein tidak cukup berisiko mengalami malnutrisi 1,56 kali lebih besar $(\mathrm{Cl} 0,91-2,67)$ daripada subjek dengan asupan protein cukup. Pada uji statistik, terlihat adanya pengaruh yang signifikan antara asupan energi terhadap malnutrisi $(p<0,05)$, sedangkan pada protein tidak ada pengaruh yang signifikan terhadap malnutrisi $(p>0,05)$ (Tabel 5).

Analisis multivariat dilakukan untuk melihat risiko asupan makanan dan variabel lain terhadap terjadinya malnutrisi di rumah sakit. Hasil dari analisis ini terlihat bahwa asupan energi, jenis kelamin dan asal rumah sakit bermakna signifikan dengan malnutrisi $(p<0,05)($ Tabel 6$)$.

Subjek dengan asupan energi tidak cukup berisiko 3,2 kali lebih besar untuk mengalami malnutrisi dibandingkan subjek dengan asupan energi cukup, subjek dengan jenis kelamin perempuan 
Tabel 5. Faktor-faktor yang Mempengaruhi Asupan Makan Responden Selama di Rumah Sakit

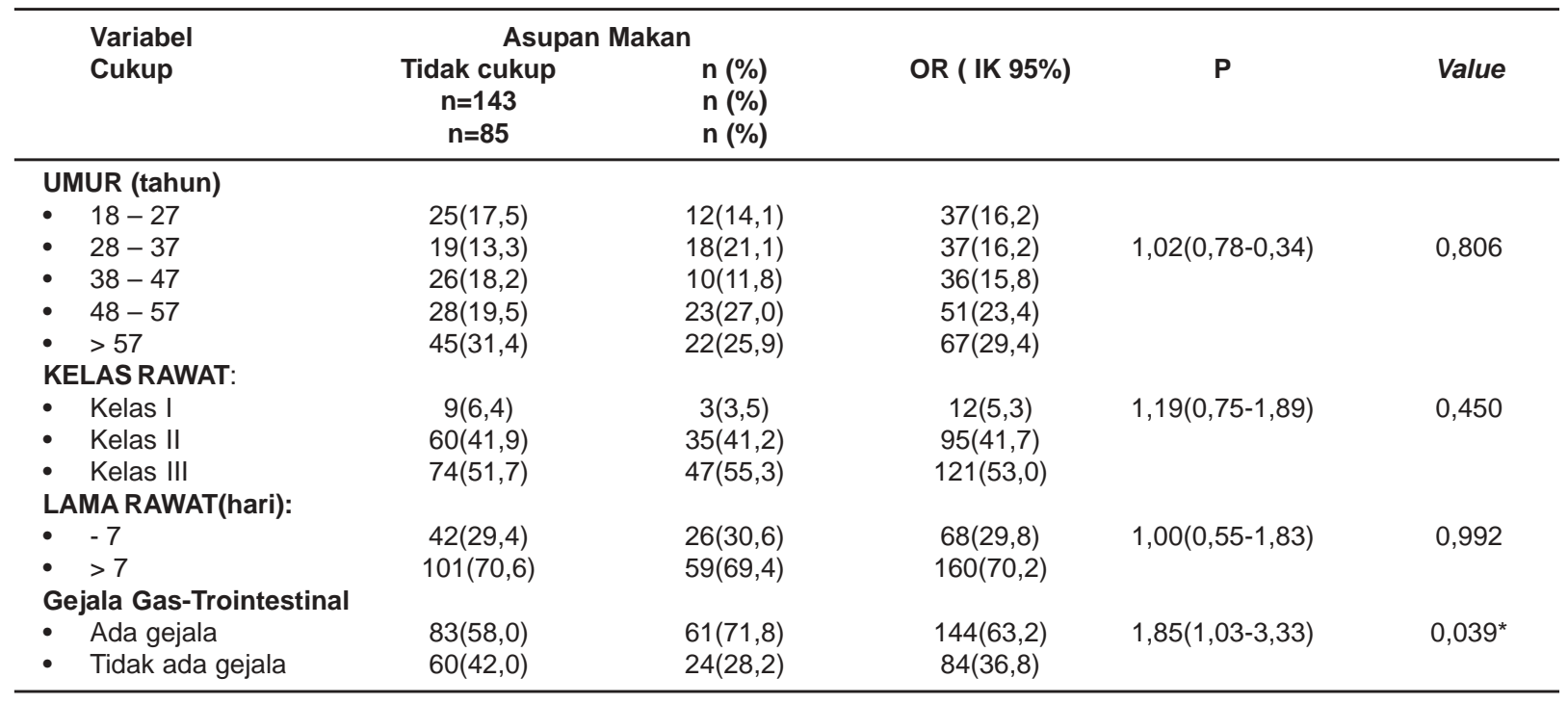

* Bermakna dengan uji Chi Square $\mathrm{p}<0,05$

Tabel 6. Pengaruh Asupan Makanan (Energi dan Protein) Selama di Rumah Sakit terhadap Kejadian Malnutrisi

\begin{tabular}{rrrrrr}
\hline Variabel & Malnutrisi & Tidak Malnutrisi & $\mathbf{n}(\%)$ & OR ((Cl 95\%) & P Value \\
\hline 1. Asupan Energi & & & & & \\
$\quad$ - Tidak Cukup & $49(57,65)$ & $36(42,35)$ & $85(100)$ & $2,11(1,23-3,65)$ & $0,007^{*}$ \\
- Cukup & $56(39,16)$ & $87(60,84)$ & $143(100)$ & & \\
2. Asupan Protein & & & & \\
$\quad$ - Tidak Cukup & $47(52,81)$ & $42(47,19)$ & $89(100)$ & $1,56(0,91-2.67)$ & 0,102 \\
$\quad$ - Cukup & $58(41,73)$ & $81(58,27)$ & $139(100)$ & & \\
\hline
\end{tabular}

* Bermakna dengan Uji Chi Square $(p<0,05)$

berisiko 2 kali lebih besar untuk mengalami malnutrisi dibandingkan dengan subjek laki-laki, serta subjek yang dirawat di RS Dr. Sardjito Yogyakarta dan RS Dr.M. Jamil Padang berisiko 4,9 dan 2,6 kali lebih besar untuk malnutrisi bila dibandingkan dengan subjek yang dirawat di RS Sanglah Denpasar (Tabel 6).

Berdasarkan hasil penelitian ini, ditemukan bahwa sebanyak $51,8 \%$ subjek mempunyai rata-rata asupan 3 hari pertama (asupan awal) tidak cukup. Tidak cukupnya asupan ini berlangsung beberapa hari selama dirawat inap bahkan ada beberapa subjek yang asupannya terus menerus tidak cukup sejak awal masuk sampai dengan keluar rumah sakit. Hal ini dapat ditunjukkan dengan rata-rata asupan selama dirawat di rumah sakit. Rata-rata asupan makanan subjek selama di rumah sakit pada kelompok asupan awal tidak cukup lebih rendah daripada asupan awal cukup yaitu untuk energi 1315,6 Kkal dengan SD \pm 343,4 dan protein 40,4 gram dengan SD $\pm 11,3$. Jika rata-rata asupan subjek selama di rumah sakit ini dilihat tingkat kecukupannya, maka terlihat sebanyak
$98,8 \%$ subjek mempunyai asupan tidak cukup untuk energi dan $86,5 \%$ untuk protein. Tidak cukupnya asupan makanan ini dapat disebabkan oleh adanya gejala gastrointestinal yang dirasakan oleh subjek (Tabel 7). Gejala gastrointestinal ini sudah dirasakan subjek sejak awal masuk hingga beberapa hari selama dirawat, bahkan ada beberapa subjek yang tetap merasakan gejala gastrointestinal sampai dengan keluar rumah sakit. Gejala yang sering dirasakan adalah gejala mual, muntah, dan anoreksia. Hasil dari uji statistik menunjukkan ada hubungan yang signifikan antara asupan awal (rata-rata asupan 3 hari pertama) dengan rata-rata asupan makanan selama di rumah sakit $(p<0,05)$.

Jika kebutuhan minimal energi tidak dapat dipenuhi dalam waktu yang lama, maka akan timbul gejala kurang gizi. Kurang gizi ini dapat dilihat dari penurunan berat badannya (malnutrisi)(6). Persentase penurunan berat badan (malnutrisi) pada penelitian ini cukup tinggi yaitu sebesar $46,1 \%$. Semua subjek yang mengalami penurunan berat badan ini termasuk pada kategori penurunan berat badan ringan (malnutrisi 
Tabel 7. Analisis Multivariat untuk Melihat Pengaruh Asupan Makanan dan Variabel Lain terhadap Kejadian Malnutrisi di Rumah Sakit

\begin{tabular}{|c|c|c|c|c|c|c|}
\hline & Variabel & $\begin{array}{l}\text { Odds } \\
\text { Ratio }\end{array}$ & $\begin{array}{l}\text { Standar } \\
\text { Error }\end{array}$ & $\chi^{2}$ & $\begin{array}{c}P \\
\text { Value }\end{array}$ & $\begin{array}{c}95 \% \\
\text { Conf. Interval }\end{array}$ \\
\hline \multirow[t]{3}{*}{1.} & Asupan Energi & & & & & \\
\hline & - Tidak cukup & 3,2 & 1,1 & 3,4 & $0,001^{*}$ & $1,7-6,3$ \\
\hline & - Cukup & 1 & - & - & - & - \\
\hline \multirow[t]{9}{*}{2.} & Penyakit & & & & & \\
\hline & - Penyakit Infeksi & & & & & \\
\hline & $\mathrm{Ya}$ & 0,8 & 0,7 & $-0,2$ & 0,814 & $0,2-4,3$ \\
\hline & $\begin{array}{ll}\text { Tidak } \\
\text { - } \\
\text { Penyakit Noninfeksi }\end{array}$ & 1 & & & & \\
\hline & Ya & 1,4 & 1.2 & 0,4 & 0.702 & $0.3-7.1$ \\
\hline & Tidak & 1 & & & & ו, \\
\hline & - Anemia & & & & & \\
\hline & $\mathrm{Ya}$ & 4,9 & 5,4 & 1,4 & 0,150 & $0,5-42,2$ \\
\hline & Tidak & 1 & & & & \\
\hline \multirow[t]{3}{*}{3.} & Jenis Kelamin & & & & & \\
\hline & - Perempuan & 0,5 & 0,2 & $-2,3$ & 0,021 & $0,3-0,9$ \\
\hline & - Laki-laki & 1 & & & & \\
\hline \multirow[t]{4}{*}{4.} & Asal Rumah Sakit & & & & & \\
\hline & - Sardjito & 4,9 & 2,1 & 3,7 & $0,000^{*}$ & $2.1-11,3$ \\
\hline & - M.Jamil & 2,6 & 0,9 & 2,5 & 0,014 & $1,2-5,5$ \\
\hline & - Sanglah & 1 & & & & \\
\hline \multirow[t]{3}{*}{5.} & Terapi Medis & & & & & \\
\hline & $-\quad Y a$ & 1,6 & 0,5 & 1,4 & 0,172 & $0,5-37,3$ \\
\hline & - Tidak & 1 & & & & \\
\hline
\end{tabular}

* Bermakna dengan uji regresi logistik ganda $(p<0,05)$

ringan) yaitu kurang dari 10\%. Menurut Roesli (7), pasien yang mengalami penurunan berat badan kurang dari $10 \%$ disebut dengan penurunan ringan atau malnutrisi ringan, $10-20 \%$ penurunan sedang atau malnutrisi sedang, dan lebih dari $20 \%$ merupakan penurunan berat (malnutrisi berat).

Hasil penelitian ini tidak jauh berbeda dengan yang dikemukakan oleh Daldiyono dan Thaha (4) bahwa dari $40-55 \%$ pasien mengalami malnutrisi atau memiliki risiko malnutrisi, $12 \%$ di antaranya dikategorikan malnutrisi berat. Penelitian Naber et al. (5) menunjukkan bahwa sebanyak $64 \%$ di antara pasien yang dirawat di rumah sakit mengalami malnutrisi.

Berdasarkan hasil penelitian ini, terlihat bahwa ada pengaruh yang signifikan antara asupan energi dengan malnutrisi $(p<0,05)$. Dilihat dari Odds Ratio subjek dengan asupan energi tidak cukup mempunyai risiko 2,1 kali lebih besar dibandingkan dengan subjek dengan asupan energi cukup. Ini berarti bahwa dukungan gizi pada penderita yang dirawat di rumah sakit sangat diperlukan, seperti penelitian yang dilakukan oleh McWhirter dan Pennington (3) yang menunjukkan bahwa pasien yang mendapatkan dukungan nutrisi yang tepat ternyata mengalami kenaikan berat badan rata-rata sebesar $7,9 \%$. Pada analisis multivariat terlihat bahwa
RS Dr. Sardjito paling berisiko terjadi malnutrisi, yaitu 4,9 kali lebih besar dibandingkan faktor risiko yang lain. Tingginya risiko ini disebabkan karena persentase penyakit noninfeksi dan terapi medis cukup tinggi dibandingkan dua rumah sakit lainnya, yaitu berturut-turut sebesar $80 \%$ dan $43 \%$. Berdasarkan penelitian Naber et al. (5), ditemukan bahwa pasien yang infeksi dan noninfeksi berisiko mengalami malnutrisi berturut-turut sebesar 1,4 dan 1,5 kali. Hal ini berarti risiko pasien yang menderita penyakit noninfeksi lebih besar daripada yang menderita penyakit infeksi.

Faktor lain yang paling berisiko untuk malnutrisi adalah asupan energi. Subjek dengan asupan energi tidak cukup berisiko 3,2 kali lebih besar daripada subjek dengan asupan energi cukup. Risiko untuk terjadinya malnutrisi ini dapat diminimalkan apabila rata-rata asupan minimal pasien yang dirawat di rumah sakit dapat dipenuhi. Asupan pasien dikategorikan cukup selama dirawat di rumah sakit bila rata-rata asupan makanannya lebih dari $75 \%$ dibanding kebutuhan energi dan $80 \%$ dibanding kebutuhan protein. 


\section{KESIMPULAN DAN SARAN}

Berdasarkan hasil penelitian ini, dapat ditarik kesimpulan yaitu rata-rata asupan energi dan protein selama di rumah sakit berhubungan dengan rata-rata asupan tiga hari pertama dirawat di rumah sakit dan pasien dengan asupan energi tidak cukup selama di rumah sakit mempunyai risiko lebih besar untuk malnutrisi dibandingkan dengan pasien dengan asupan energi cukup.

Bertitik tolak dari hasil penelitian ini, penulis menyarankan perlunya ditingkatkan asupan makanan pasien selama di rumah sakit terutama dari sumber energi untuk mengurangi kejadian malnutrisi di rumah sakit. Asupan makanan ini dapat ditingkatkan bila ada kerjasama antar tenaga medis di rumah sakit.

\section{Ucapan Terima Kasih}

Terima kasih yang tak terhingga penulis sampaikan pada RS Dr Sardjito, RS Dr. M. Jamil, dan RS Sanglah serta pihak-pihak yang membantu penelitian ini sehingga penulis dapat menyelesaikannya dengan baik.

\section{RUJUKAN}

1. Soegih R. Pola Penanganan Kasus Gizi di Puskesmas dan Rumah Sakit. Dalam Daldiyono dan Thaha AR, editors. Kapita Selekta Nutrisi Klinik. Jakarta: Perhimpunan Nutrisi Enteral dan Parenteral Indonesia; 1998.

2. Braunschweig C, Gomez S, and Sheean PM. Impact of declines in nutritional status on outcomes in adult patients hospitalized for more than 7 days. J Am Diet Assoc 2000;100:1316-22.

3. McWhirter JP, and Pennington CR. Incidence and recognition of malnutrition in hospital. British Medical Journal 1994;308:945-8.

4. Daldiyono dan Thaha AR. Kapita Selekta Nutrisi Klinik. Jakarta: Perhimpunan Nutrisi Enteral dan Parenteral Indonesia; 1998.

5. Naber THJ, T Schermer, A Bree, et al. Prevalence of Malnutrition in Nonsurigical Hospitalized Patients and Its Association with Disease Complication, Am J Clin Nutr 1997;66:1232-9.

6. Dawiesah S. Nutrisi dan Kesehatan. Proyek Pengembangan Pusat Antar Universitas Pangan dan Gizi. Yogyakarta: Universitas Gadjah Mada; 1990.
7. Roesli RMA, Surahman E, dan Suroto EH. DasarDasar Terapi Nutrisi Parenteral Pada Dewasa dan Anak. Bandung: Kelompok Studi Terapi Cairan, Enteral dan Parenteral; 1997. 